\title{
LEVEL AND PACE OF THE REGIONAL DEVELOPMENT OF BOSNIA AND HERZEGOVINA IN THE CONTEXT OF INTEGRATION INTO THE EUROPEAN UNION
}

The main goal of this paper is to assess the level and pace of regional development of Bosnia and Herzegovina on the one hand, and the EuroAtlantic path of Bosnia and Herzegovina as a potential candidate for EU membership on the other. In the empirical part of the research, the spatial component encompassed the regionalization of Bosnia and Herzegovina. The research also included an analysis of the process of the integration of Bosnia and Herzegovina into the European Union from the aspect of preaccession assistance to candidate countries and potential candidates in the function of promoting regional development. The primary research of regional development and assessment of the level of development as well as the scope of structural policies in overcoming the key political, social and economic problems that hinder the development and improvement of the economic integration of Bosnia and Herzegovina towards the European Union are limited to the territory of Bosnia and Herzegovina. The basic scientific methods used in the work and for giving answers to research questions are historical and comparative methods. They consist of methods and indicators of statistical analysis (indices, growth rates, participation rates, coefficients, averages). Specific scientific methods used in the process of this work are: the method of analysis, the synthesis method, the induction method, the descriptor method, the deduction method, the classification method and

* V. Tulumović, PhD, University of Tuzla, Faculty of Economics - Tuzla (e-mail: vanestulumovic@yahoo.com).This workwas created based on the results of empirical research from the doctoral dissertation of the author of this paper at the Faculty of Economics at the University of Tuzla. The paper was received on 09.01.2019. It was accepted for publication on 18.03.2019. 
V.TULUMOVIĆ: Level and pace of the regional development of Bosnia and Herzegovina in the context of integration... EKONOMSKI PREGLED, 71 (2) 152-172 (2020)

the comparison method. The empirical results of the research confirm that Bosnia and Herzegovina is faced with the problem of regional development with a pronounced imbalance between the areas within the whole territory of Bosnia and Herzegovina. This is a confirmation for the need for systemic policy as well as regional development policy at the level of Bosnia and Herzegovina that would be in line with the policies of the European Union.

Keywords: regional development, regional development policies, integration into the $E U$.

\section{Introductory considerations}

The regional policy of the European Union is a matter of growing interest in candidate countries and potential full membership candidate countries, because the preparation has already started due to the use of pre-accession funds for structural funds and cohesion funds, which are only available to member states. Regionalization in Bosnia and Herzegovina is also necessary in the context of joining the European Union. Establishing a regional structure is one of the prerequisites for inclusion in the regional development policy of the European Union and for access to development funds that stimulate the country's balanced economic development. The necessity of establishing a regional development policy at the level of Bosnia and Herzegovina is one of the key factors for successful economic development and overcoming or alleviating regional imbalances at the level of development, especially from the point of view of local units as bearers of economic development. Therefore, in the following, with greater detail, the importance of regional policy at the level of Bosnia and Herzegovina will be shown with a focus on the European Union. The subject of the analysis in this paper is to bring closer the significance of regional development in the function of overall economic development, with a special emphasis on Bosnia and Herzegovina. Some of the research questions that arise in the analysis of regional development have a spatial and economic character, so we highlight the following:

$>$ How important is spatial allocation in overcoming regional underdevelopment?

$>$ What are the causes and consequences of regional underdevelopment?

$>$ The significance of EU integration to the regional development policy of $\mathrm{BiH}$ ?

The importance of adopting regional development policy at the level of Bosnia and Herzegovina, as well as other issues of relevance to the subject of study? 
One of the objectives of the research in the work is to determine the role of the pre-accession assistance policy of the European Union (IPA) which, based on the results of the analysis of the research in the paper, directly or indirectly influenced the regional development in Bosnia and Herzegovina, and remains one of the key development levers in overcoming regional and general underdevelopment.

\section{Importance and content of regional development}

In the economic development of any area, branch or structural dimension, a spatial component is also very important. In general, the region is a territory with a recognizable local, administrative, cultural, political significance or economic power and cohesiveness. The region can therefore be defined as a territory in which the interaction between market actors and flows creates a regional economic system, and the boundaries determined by the point at which the magnitude of these interactions and flows is changing from one direction to another (Cooke, 2004).

Bogunović (1991) links the significance of the regional component with the need for coordination of sector and regional policies for a more efficient development of the whole economy; with continuous interregional cooperation from which production specialization results in relation to the comparative (competitive) advantages of certain areas and with effects in better exploitation of regional potentials.

Šverko (1995) identifies in the efficient management of regional development the possibilities to mitigate regional inequalities (economic, social); the need to accelerate the development of regions and national economies; the possibilities for optimal use of specific development and other potentials at local and regional levels and the possibility of establishing a rational sector and territorial division of labor.

Kantalić (2005) sees the importance of regional development in "increasing the efficiency of national economic development and achieving balanced development among the regions." He points out that regional policy should create optimal conditions for the development of regions in order to increase the economic power of the entire regional area. The lacking of the current regional policy towards Kantalic (2005) is that "the emphasis on economic development is increasingly focused on the regional balance and the exploitation of development factors in order to improve the economic situation of the lagging regions." The policy of regional development according to Rubić (1999) implies "building and defining the concepts, strategies, goals, tasks and current economic policy measures and their 
realization at different territorial levels. It is based on the compatibility of regional, branch and global policies. Regional economic policy is characterized by a system of coherent relations that directs regional development, and works to stimulate the development processes that improve the economy of the region."

If we take a look at Bosnia and Herzegovina, it can be seen that the market transformation is reduced to macroeconomic stabilization, that the country enjoys the stability of only the so-called nominal economic indicators (stability and convertibility of the domestic currency, fixed exchange rate and low inflation rate). However, even this kind of stability is, on the one hand, handicapped by the entity structure that denies the state of macroeconomic policy, and on the other, it does not correspond with real economic progress. In contrast to the nominal, real economic indicators show the economic lagging of the country (the constantly high unemployment rate, the high deficit of trade and balance of payments, the sustainability of external debt with international assistance and transfers from abroad and, hopefully, the rate of economic growth insufficient not only for the immediate closure of the economic gap according to the European Union, but also to reach the level of income of countries from the last fifth enlargement of the European Union), (Hodžić, 2010).

Successful economic development in Bosnia and Herzegovina, according to Hodžić (2009), would focus on two directions: "anticyclical policy and the opening of a new approach to Bosnian and Herzegovinian integrity with a changed theoretical-ideological paradigm and the concept of integrating economic and social development." Osmanković (2001) differentiates the motives of regional policy into economic and political ones. These motives are economically identified in realizing the need for balanced development, solving inadequacies and optimizing profits on the basis of an adequate allocation of capital in production. They are politically manifested in eliminating dissatisfaction of the population of underdeveloped areas, reducing population migrations and others.

\section{Bosnia and Herzegovina from the aspect of regionalization and level of economic development}

In a theoretical analysis of the research, many authors point out whether regionalization is a cause or consequence of some regions developing faster than others and that there are significant differences in the level of social, economic and overall well-being of the region. According to the above, it is clear that these issues are also present in Bosnia and Herzegovina (Barbić, 2010). The regionalization of Bosnia and Herzegovina can be classified into three basic groups: Scientifically 
founded regionalizations presented in the works of Bosnian and Herzegovinian authors, military-political regionalization prepared by international experts and administrative regionalization as a kind of economic and regional policy.

Regionalization and Centers of Socio-Economic Development in Bosnia and Herzegovina is a proposal for the division of $\mathrm{BiH}$ into four macro-regions and sixteen regions, (Osmanković, 2002): 1) Macro-region Bosanska Krajina with five regions; 2) Macro-region Sjevernoistočna (Northeastern) Bosna with four regions; 3) Macro-region Sarajevo-Zenica with three regions; 4) Macro-region Herzegovina with four regions: Mostar, Trebinje, Konjic and Livno.

The model of four regions is derived as a function of the geographical space, number and structure of the population and socio-economic development. The regionalization was realized in the following procedure: Firstly, the theoretical model based on the research of gravitational effects for all four centers was established. On this basis, the established boundaries were corrected by the results of the survey on the actual gravity orientation of individual areas. The second model correction was made on the basis of the assessment of the spatial and geographical conditions of the interconnection of the municipalities. Proposed regionalization is defined as spatially and demographically large enough regions with such a structure that allows their functioning. They were supposed to be balanced in their economic, social and other abilities. Accordingly, $\mathrm{BiH}$ is divided into four regions: Banja Luka-Bihać (Bosanska Krajina), Sarajevo-Zenica (Central Bosnia), TuzlaDoboj (Sjeveroistočna (Northeastern) Bosna) and Mostar-Trebinje (Herzegovina), (Bošnjaković, 1992).

The meaning of this model is in its design and effectiveness in opening up the possibilities for solving the basic problems of development and in the economic, political, ethnic and administrative motives that are respected. In March 1993, according to the "Vence-Owen Plan", a division was proposed into ten provinces, three for each nation, and a special status for Sarajevo. According to this proposal the provinces would have a national sign. In August of the same year (1993) according to the plan of Owen-Stoltenberg, the division of constituent republics was proposed: Bosniacs, Croats and Serbs with the administration of the European Union over the city of Mostar and a special status for Sarajevo (Begić, 1997) is envisaged.

According to the Washington Treaty of May 1994, the division of Bosnia and Herzegovina into the Federation of Bosnia and Herzegovina, a territorial unit with the majority of Serbian people and the city Sarajevo as a district is envisaged. The map is a result of respecting the ethnic principle. This division, with certain border corrections, has been retained in the Contact Group's plan since July 1994 and according to this plan, $\mathrm{BiH}$ consists of the Federation of Bosnia and Herzegovina, Republic of Srpska and the Sarajevo District. 
In relation to the previous proposal, the degree of unification of national corps is higher. The ethical principle here is consistently respected with certain deviations. Finally, according to the Dayton Peace Agreement, a division into two entities is envisaged: the Federation of Bosnia and Herzegovina and the Republic of Srpska alongside the city of Brčko as the territory of arbitration. The Federation of Bosnia and Herzegovina is divided into ten cantons (Una-Sana, Posavina, Tuzla, Zenica-Doboj, Bosnian-Podrinje, Central Bosnia, HerzegovinaNeretva, West Herzegovina, Sarajevo and Herzeg-Bosna) and the cantons are divided into municipalities. The Republic of Srpska is divided into municipalities (Pejanović, 2008).

The current regionalization of Bosnia and Herzegovina can be observed in three moments: Administrative regionalization, regionalization in the areas of newly formed regional development agencies and regionalization according to the vision of the European Commission. The third potentially topical regionalization is the vision of the European Commission to divide the territory of Bosnia and Herzegovina into five regions: Sarajevo Economic Region, Northwest Bosnia (Tuzla), Southeast Bosnia (Mostar), Central Bosnia (Zenica), Northwest Bosnia (Banja Luka), (Osmanković, 2004).

Bosnia and Herzegovina, in the process of integration into the European Union, is facing the challenges of regionalization, interregional cooperation with neighboring countries, as well as the possibilities of economic and social development of the country through the support of the Structural Funds offered by the European Union. Regionalization is not only a prerequisite for accessing the European Union's funds for regional development but also an increasingly important factor in the process of overall European integration, which $\mathrm{BiH}$ is also a part of.

Acceptance and application of the Euro-region concept in Bosnia and Herzegovina, in addition to opening up the possibility of accessing the funds of the European Union for regional development, would contribute to the internal political and economic integration of Bosnia and Herzegovina, as well as the fulfillment of conditions for admission of the country to EU membership. The efficiency of the administrative territorial organization has been the subject of numerous analysis, surveys, public inquiries, academic circles, domestic and international experts. Simply, the following conclusions were reached: The first conclusion is that the administrative organization as a whole is inefficient, that it is expensive, irrational, not flexible, engages too much budget funds, it is not economically and demographically sustainable, it does not have the necessary capacity to absorb technical assistance, programs and funds of the European Union, but also other bilateral and multilateral partners, it is an obstacle to the economic and overall development, an obstacle to the process of Bosnia and Herzegovina's integration into the European Union (Osmanković, 2014). 
The regionalization of Bosnia and Herzegovina must be considered in the context of the modern integration processes of the European Union based on the nomenclature of statistical territorial units of the NUTS region. Respecting the EU criteria on region and regionalization, Bosnia and Herzegovina could be regionally regulated at the hierarchical level of the NUTS - two regions. It is possible to regionalize Bosnia and Herzegovina according to the European NUTS standards in the Banja Luka macro-region spreading 15,210 km² with 1.078 .099 inhabitants or $28,4 \%$, the Tuzla macro-region spreading $10.393 \mathrm{~km}^{2}$ with 1.260 .059 inhabitants or 33,2\%, the Sarajevo macro-region spreading $10.495 \mathrm{~km}^{2}$ with 955.477 inhabitants or $25,1 \%$, the Mostar macro-region spreading $15.031 \mathrm{~km}^{2}$ with 497.987 inhabitants or $13,1 \%$ of the total population of Bosnia and Herzegovina. NUTS regionalization of Bosnia and Herzegovina is an imperative of the process of integration into the European Union. The European regional-geographical concept applied in the territory of Bosnia and Herzegovina must, among other things, respect the cross-border regional-geographical division of neighboring countries in full compatibility capacity (Spahić, 2014).

Bosnia and Herzegovina is on the Euro-Atlantic path and also in the process of meeting conditions for obtaining candidate status. Economic trends in the country are unfavorable, the rise in prices, job losses, reduction of foreign direct investments and the process of European integration as a start-political commitment and a start-up framework for the overall democratic and economic development of the country are on the scene. Analyzing the gross domestic product achieved on the territory of Bosnia and Herzegovina in the period from 2006 to 2016, the realized GDP grew at a rate of 4,0\%, i.e. from 20,0 billion BAM in 2006 to 29,9 billion BAM in 2016. Observed in intermediate periods, the growth rate in the period 2006-2011 is higher and ranges around 5,5\%, and in the period 2012-2016, it is slightly less than about 3,3\%. The manufacturing industry, in the period 20062016 , achieved a growth rate of gross domestic product of 6,3\%. Special attention is noted in the growth of trade activity, which in the period 2006-2016, achieved a growth rate of 5,2\% and a GDP level of 4,03 billion BAM in 2016.

Significant growth rates were also recorded in administrative and auxiliary service activities $(7,1 \%)$, professional, scientific and technical activities $(5,6 \%)$, education $(5,2 \%)$, financial activities $(5,0 \%)$, mining $(4,8 \%)$, health and social protection $(6,4 \%)$, art and recreation $(10,6 \%)$. In manufacturing (agriculture, forestry and fishery, mining and quarrying, manufacturing, production and supply of electricity, water and construction), 34,7\% of added value is created and 65,2\% in service industries. In 2017, a slight recovery of the economy continued in Bosnia and Herzegovina, and according to preliminary data, the annual growth rate of real GDP was 3\%. Real growth of gross value added in 2017, was recorded in almost all areas of economic activity, except for the following activities: agriculture, forestry, electricity production and supply, real estate and scientific activities. 
In 2017, the largest contribution to the growth of real GDP was given by the manufacturing and wholesale and retail trade, and their share in generating gross value added increased in relation to 2016 . The average nominal net salary in 2017 , amounted to 851 BAM and it increased by $1,5 \%$ in comparison with the previous year. Growth of average nominal net salary was recorded in all activities, except education and other service activities. Real individual consumption per capita and GDP per capita in 2017 also do not show that significant progress has been made in the level of well-being. Both indicators remained at an extremely low level in 2017, which is why Bosnia and Herzegovina significantly lagged, not only in relation to the European average, but also in relation to the countries in the region.

In 2017, the real growth of gross value added was generated by the growth of activity in most economic activities, and the most prominent were: Services $(31,1 \%)$, arts and entertainment $(10,1 \%)$, trade $(9,7 \%)$, mining 5,3\%), the financial sector $(4,6 \%)$, the manufacturing industry $(4,1 \%)$. On the other hand, the drop in gross value added was recorded in: Civil, scientific and technical activities $(-4,4 \%)$, agriculture $(-3,5 \%)$, production and supply of electricity $(-1,0 \%)$, transport and storage $(-0,8 \%)$. According to the projection of the International Monetary Fund, the nominal social product in Bosnia and Herzegovina is 31,283 billion BAM for 2017, which represents a growth of $4,6 \%$ in relation to the previous year. The projection of the real GDP growth rate in relation to the previous year is $2,7 \%$. In the economy of Bosnia and Herzegovina, the total number of employees in 2016 is at the level of 719.150 persons. When it comes to the rate of employment growth in the period 2013-2016, it is at the level of $4,1 \%$, while the employment rate in relation to the working age population is $89,0 \%$. The employment rate in relation to the population is $20,4 \%$.

In the labor market, according to administrative data and the Labor Force Survey in 2017, there is a decrease in the number of unemployed. The unemployment rate in Bosnia and Herzegovina is at the level of 20,5\% and it is lower than in 2016 by 4,9\%. The administrative unemployment rate in December 2017 was $38,7 \%$ and was lower by $2,2 \%$ compared to December of the previous year. The fact that the unemployment rate of young people has decreased by 8,5 percentage points compared to the previous year cannot be interpreted solely by the improvement of the labor market conditions, because partly it is a lower unemployment rate and the reduction in the number of young people in the labor force due to an increasingly intensive trend of departure of young people abroad. If these are the causes and factors that decisively determined the existing state, according to Hodžić (2011) they are "of a twofold nature, i.e., both structural and cyclical." Problems on labor markets are partly inherited from the pre-war period, and partly as a result of the inadequate transition policy and the organization of the labor market. 
All four quarters in 2017, observed on an annual basis, are characterized by the growth of industrial production. Owing to this quarterly trend, the volume of industrial production realized in 2017 increased by 3,1\%. Furthermore, the area where growth was also achieved, at a rate of 5,0\%, is the extraction of ore and stone. Within this area, the activity of extraction of coal and lignite has been recorded. The most significant contribution to the growth of industrial production in 2017, observed by area of activity, was recorded by the manufacturing industry (annual growth of 5,3\%), while the negative contribution to growth was recorded in the production and supply of electricity and gas (annual decline of 4,1\%). In the economic activity of construction, the production volume declined in 2017, which is by $2,5 \%$ less than in the previous year. The decrease in the production index in construction is under the influence of the decline in the segment of civil engineering, which is by $4,9 \%$ less than in the previous year, while the construction of buildings has increased in comparison with the previous year $(3,6 \%)$. The decline in civil engineering activities is particularly related to the delay in the construction of the Corridor $5 \mathrm{c}$.

Trade as a single activity has the largest share in gross value added, which in the three quarters of 2017 is 17,3\%. Observing distributive trade statistics, which include all forms of trading activities, from the procurement of goods from the manufacturer to the delivery of goods to the final consumer on the domestic market, it is evident that in all four quarters of 2017 the trade turnover recorded significant growth, which at the annual level is $8,0 \%$, primarily as a result of the growth of the activities in wholesale trade and intermediation in trade (annual growth of 9,3\%) and retail trade, which records continuous growth of turnover in the last years, which at the end of 2017 is 4,5\% in relation to the previous year.

Comparing the contribution of growth in real gross value added to activities in Bosnia and Herzegovina with contributions to its growth in the European Union, for 2017, it is noticeable that the annual growth of this structure of gross value added has some similarities and important structural differences. The most significant contribution to the growth of gross value added, in Bosnia and Herzegovina as well as in the European Union, have: Trade, transport, catering and industrial production. On the other hand, the highest growth in gross value added in the European Union is recorded by construction $(4,5 \%)$, while in Bosnia and Herzegovina it is significantly lower $(1,1 \%)$ as a result of slowed down infrastructure investments. At the same time, EU agriculture recorded growth $(1,2 \%)$, while in Bosnia and Herzegovina it recorded a real decrease. In the period 2006-2016, the volume of foreign trade of Bosnia and Herzegovina grew from 16,5 billion to 25,5 billion BAM, and on the other hand, coverage in 2006 amounted to 45,0\%, while in 2016 at the level of 58,3\%. 
V.TULUMOVIĆ: Level and pace of the regional development of Bosnia and Herzegovina in the context of integration... EKONOMSKI PREGLED, 71 (2) 152-172 (2020)

Table 1.

OVERVIEW OF FOREIGN TRADE OF BOSNIA AND HERZEGOVINA FOR THE PERIOD 2006 - 2016 IN 000 BAM

\begin{tabular}{|l|c|c|c|c|c|}
\hline Period & $\begin{array}{c}\text { Commodity } \\
\text { exchange }\end{array}$ & Export & Import & Balance & Coverage \\
\hline 2006 & 16.553 .081 & 5.164 .296 & 11.388 .785 & -6.224 .489 & 45,0 \\
\hline 2007 & 19.834 .826 & 5.936 .584 & 13.898 .242 & -7.961 .658 & 42,7 \\
\hline 2008 & 23.004 .206 & 6.711 .690 & 16.292 .516 & -9.580 .826 & 41,2 \\
\hline 2009 & 17.886 .378 & 5.531 .199 & 12.355 .179 & -6.823 .980 & 44,8 \\
\hline 2010 & 20.711 .741 & 7.095 .503 & 13.616 .238 & -6.520 .735 & 52,1 \\
\hline 2011 & 23.748 .296 & 8.222 .163 & 15.526 .133 & -7.303 .970 & 53,0 \\
\hline 2012 & 23.111 .383 & 7.858 .340 & 15.253 .043 & -7.394 .703 & 51,5 \\
\hline 2013 & 23.550 .668 & 8.380 .496 & 15.170 .172 & -6.789 .676 & 55,2 \\
\hline 2014 & 24.881 .020 & 8.681 .742 & 16.199 .278 & -7.517 .536 & 53,6 \\
\hline 2015 & 24.839 .178 & 8.987 .315 & 15.851 .863 & -6.864 .548 & 56,7 \\
\hline 2016 & 25.579 .123 & 9.418 .109 & 16.161 .014 & -6.742 .905 & 58,3 \\
\hline
\end{tabular}

Source: Agency for Statistics of Bosnia and Herzegovina, various years.

According to the empirical results, $\mathrm{BiH}$ has a developed export-import network. It is important to distinguish the countries to which Bosnia and Herzegovina exported the most. According to Table 2, in the period 2013-2016, the most export is transferred with Germany: 1,4 billion BAM or 15,7\% of total exports, followed by Italy with 1,1 billion BAM, which represents $12,0 \%$ of the share, then Croatia with 985,3 million BAM or $10,5 \%$, Serbia with 822,8 million BAM or $8,7 \%$ of the share, and others as follows in Table 2. 
Table 2.

COUNTRIES TO WHICH BOSNIA AND HERZEGOVINA EXPORTED THE MOST IN THE PERIOD 2013- 2016 IN 000 BAM

\begin{tabular}{|l|r|r|r|r|r|r|r|r|}
\hline Country & $\mathbf{2 0 1 3}$ & $\begin{array}{r}\text { B\&H } \\
\mathbf{= 1 0 0}\end{array}$ & $\mathbf{2 0 1 4}$ & $\begin{array}{r}\text { B\&H } \\
\mathbf{= 1 0 0}\end{array}$ & $\mathbf{2 0 1 5}$ & $\begin{array}{l}\text { B\&H } \\
\mathbf{= 1 0 0}\end{array}$ & $\mathbf{2 0 1 6}$ & $\begin{array}{r}\text { B\&H } \\
=\mathbf{1 0 0}\end{array}$ \\
\hline Germany & 1.310 .844 & 15,6 & 1.317 .490 & 15,2 & 1.412 .906 & 15,7 & 1.479 .411 & 15,7 \\
\hline Croatia & 1.194 .637 & 14,3 & 955.047 & 11,0 & 925.166 & 10,3 & 985.360 & 10,5 \\
\hline Italy & 1.003 .294 & 12,0 & 1.195 .438 & 13,8 & 1.214 .930 & 13,5 & 1.131 .096 & 12,0 \\
\hline Slovenia & 686.504 & 8,2 & 697.785 & 8,0 & 748.870 & 8,3 & 807.200 & 8,6 \\
\hline Austria & 687.565 & 8,2 & 755.827 & 8,7 & 743.062 & 8,3 & 730.590 & 7,8 \\
\hline Serbia & 766.759 & 9,1 & 800.690 & 9,2 & 770.695 & 8,6 & 822.846 & 8,7 \\
\hline Turkey & 174.687 & 2,1 & 234.392 & 2,7 & 354.630 & 3,9 & 401.047 & 4,3 \\
\hline Montenegro & 270.745 & 3,2 & 293.818 & 3,4 & 262.844 & 2,9 & 240.751 & 2,6 \\
\hline Czech Repub. & 152.388 & 1,8 & 148.233 & 1,7 & 131.406 & 1,5 & 142.777 & 1,5 \\
\hline Hungary & 138.721 & 1,7 & 186.652 & 2,1 & 188.742 & 2,1 & 194.579 & 2,1 \\
\hline
\end{tabular}

Source: Agency for Statistics of Bosnia and Herzegovina, various years.

According to the results of the survey, Germany is ranked first with 1,9 billion BAM of imports, which is $12,4 \%$ of total imports to Bosnia and Herzegovina in 2016. Below Germany is Italy with 1,8 billion BAM 11,8\%, Serbia with 1,8 billion BAM or $11,3 \%$ and Croatia with 1,6 billion BAM or $10,0 \%$ of the share, and other countries as follows in Table 3. 
V.TULUMOVIĆ: Level and pace of the regional development of Bosnia and Herzegovina in the context of integration... EKONOMSKI PREGLED, 71 (2) 152-172 (2020)

Table 3.

COUNTRIES FROM WHICH BOSNIA AND HERZEGOVINA IMPORTED THE MOST IN THE PERIOD 2013-2016 IN 000 BAM

\begin{tabular}{|l|r|r|r|r|r|r|r|r|}
\hline Country & $\mathbf{2 0 1 3}$ & $\begin{array}{r}\mathbf{B \& H} \\
\mathbf{= 1 0 0}\end{array}$ & $\mathbf{2 0 1 4}$ & $\begin{array}{r}\mathbf{B} \boldsymbol{A H} \\
\mathbf{= 1 0 0}\end{array}$ & $\mathbf{2 0 1 5}$ & $\begin{array}{l}\mathbf{B \& H} \\
\mathbf{= 1 0 0}\end{array}$ & $\mathbf{2 0 1 6}$ & $\begin{array}{r}\text { B\&H } \\
=\mathbf{1 0 0}\end{array}$ \\
\hline Germany & 1.734 .845 & 11,4 & 1.869 .564 & 11,5 & 1.914 .123 & 12,1 & 1.998 .877 & 12,4 \\
\hline Croatia & 1.956 .381 & 12,9 & 1.851 .693 & 11,4 & 1.673 .068 & 10,6 & 1.617 .713 & 10,0 \\
\hline Italy & 1.482 .253 & 9,8 & 1.653 .565 & 10,2 & 1.758 .287 & 11,1 & 1.899 .582 & 11,8 \\
\hline Russia & 1.506 .180 & 9,9 & 1.292 .467 & 8,0 & 910.072 & 5,7 & 729.427 & 4,5 \\
\hline China & 914.082 & 6,0 & 1.359 .548 & 8,4 & 1.091 .670 & 6,9 & 1.091 .966 & 6,8 \\
\hline Serbia & 1.485 .621 & 9,8 & 1.629 .521 & 10,1 & 1.728 .431 & 10,9 & 1.828 .142 & 11,3 \\
\hline Turkey & 493.283 & 3,3 & 582.203 & 3,6 & 644.698 & 4,1 & 687.349 & 4,3 \\
\hline Austria & 519.291 & 3,4 & 532.109 & 3,3 & 560.859 & 3,5 & 556.399 & 3,4 \\
\hline Slovenia & 754.344 & 5,0 & 763.235 & 4,7 & 773.503 & 4,9 & 831.403 & 5,1 \\
\hline Poland & 393.438 & 2,6 & 515.596 & 3,2 & 452.743 & 2,9 & 474.152 & 2,9 \\
\hline
\end{tabular}

Source: Agency for Statistics of Bosnia and Herzegovina, various years.

Although the recovery in economic activity in Bosnia and Herzegovina continued in 2017, it can be estimated that its intensity is still insufficient for the existing risks from the local environment to be significantly mitigated. Although positive trends are noted in the labor market, low purchasing power remains a limiting factor in domestic demand. The unfavorable business environment continues to be a limiting factor in attracting foreign capital, and Bosnia and Herzegovina has only slightly improved its position on the list of countries by competitiveness. According to Eurostat data in 2017, in Bosnia and Herzegovina, the GDP per capita, expressed in the purchasing power standard, was $32 \%$ of the EU28 average. Although the value of this indicator is by one percentage point higher than in 2016, Bosnia and Herzegovina is at the forefront of the 37 countries covered by the survey.

\section{Integration process into the European Union from the aspect of regional development of Bosnia and Herzegovina}

The European Partnership is conceived as a special version of the Accession Partnership with potential candidate countries in the Stabilization and Association Process and the adaptation of each country to the accession process. The European 
Partnership is a mechanism for measuring progress and forms the basis for programming the financial resources that the European Union's assistance has been provided since 2007 through IPA funds.

Bosnia and Herzegovina is focused on meeting the guidelines - the Roadmap conditions, set by the European Union as the first phase of the country's preparation for its full involvement in the integration processes. The Roadmap is a document adopted by the EU Council of Ministers in 2000, which defined 18 guidelines, that is, the conditions for the inclusion of Bosnia and Herzegovina in the European integration process and the transition to the next stages of the Stabilization and Association Process, i.e., the elaboration of the Feasibility Study and the opening of negotiations on the stabilization and association. The goal of integrating Bosnia and Herzegovina into the structures of the European Union and eventual membership in the European Union achieves widespread support in Bosnia and Herzegovina. However, in order to achieve this goal, countries should first and foremost demonstrate that they share the fundamental values of the European Union, as well as the capacity needed to fulfill the commitments stemming from the Stabilization and Association Agreement. In the period from 2008 until 2015, the integration process of Bosnia and Herzegovina is in stall.

Certain steps have been taken by the institutions of the European Union in terms of creating a new approach in helping to accelerate the integration of the state of Bosnia and Herzegovina into the European Union. It followed, in fact, a German-British initiative that provided the basis for formulating the Reform Agenda. This document is a primacy to issues of economic and social development. Political issues for which there is no consensus are postponed for some future time. These institutions of the European Union: the Commission, the Council and the Parliament of the European Union have chosen a new approach in order to accelerate the integration of Bosnia and Herzegovina into the European Union.

In 2016, Bosnia and Herzegovina submitted an application for EU membership. The application was accepted. Then, in December 2016, the European Union delivered a questionnaire to Bosnia and Herzegovina with 3.242 questions that the state institutions need to complete within six months. On February 28th 2018, Bosnia and Herzegovina submitted replies to the Questionnaire to the EU Delegation. When the answers to questions in the questionnaire are accepted, the European Commission's opinion will follow whether Bosnia and Herzegovina fulfilled the conditions for obtaining the status of candidate for EU membership (Pejanović, 2018). During the development and construction of the European Union, funds have been created for various types of EU assistance to candidate countries and potential candidates in the integration process. We will pay special attention to IPA funds.

Regarding the objectives and scope of the IPA according to the available sources of relevant institutions at the cross-section between external assistance and internal policies, the IPA intends to provide targeted assistance to candidate 
countries or potential candidates for EU membership. The IPA is divided into five different components: Transition assistance and institution building; regional and cross-border cooperation; regional development; improvement of human resources; rural development. The first two refer to potential candidates as they all refer to candidate countries. As a result, all users have access to measures of a similar nature with customized management conditions in accordance with their political, economic and administrative situation.

Table 4.

OVERVIEW OF THE FUNDS AGREED BY THE EU DELEGATION IN NOVEMBER 2011 FOR COMPONENT I: TRANSITION ASSISTANCE AND INSTITUTION BUILDING

\begin{tabular}{|c|c|c|c|c|}
\hline $\begin{array}{l}\text { Year of the } \\
\text { program }\end{array}$ & Program & $\begin{array}{c}\text { Assigned } \\
\text { (available) }\end{array}$ & $\begin{array}{c}\text { Agreed } \\
\text { (Used) }\end{array}$ & $\begin{array}{l}\% \text { assigned / } \\
\text { distribution }\end{array}$ \\
\hline 2007 & $\begin{array}{l}\text { Annual Program for Bosnia and } \\
\text { Herzegovina under the IPA Component } \\
\text { "Transition Assistance and Institution } \\
\text { Building" for } 2007 \\
\end{array}$ & 49.736 .394 & 47.992 .297 & $96 \%$ \\
\hline 2008 & $\begin{array}{l}\text { Annual Work Plan for Bosnia } \\
\text { and Herzegovina for 2008, under } \\
\text { Component } 1 \text { - Part I }\end{array}$ & 12.500 .000 & 10.958 .661 & $88 \%$ \\
\hline 2008 & $\begin{array}{l}\text { State Program for Bosnia and } \\
\text { Herzegovina for 2008, under the IPA } \\
\text { Component "Transition Assistance and } \\
\text { Institution Building" - Part II }\end{array}$ & 54.254 .783 & 38.607 .237 & $71 \%$ \\
\hline 2009 & $\begin{array}{l}\text { Annual Work Plan for Bosnia } \\
\text { and Herzegovina for 2009, under } \\
\text { Component } 1 \text { - Part I }\end{array}$ & 39.000 .000 & 39.000 .000 & $100 \%$ \\
\hline 2009 & $\begin{array}{l}\text { Annual Work Plan for Bosnia } \\
\text { and Herzegovina for 2009, under } \\
\text { Component } 1 \text { - Part II }\end{array}$ & 41.500 .000 & 11.110.097 & $27 \%$ \\
\hline 2010 & $\begin{array}{l}\text { State Program for Bosnia and } \\
\text { Herzegovina within IPA } 2010\end{array}$ & 92.288 .099 & 18.027 .493 & $20 \%$ \\
\hline 2010 & $\begin{array}{l}\text { State Program for Bosnia and } \\
\text { Herzegovina within IPA } 2010 \text { - Part II }\end{array}$ & 6.000 .000 & - & $0 \%$ \\
\hline \multicolumn{2}{|r|}{ IPA TOTAL for Component I: } & 295.279 .276 & 165.695 .785 & $56 \%$ \\
\hline
\end{tabular}

Source: http://europa.ba/?page_id=517 19.3.2018. 
The international legal basis for the acquisition and use of IPA financial assistance is the Framework Agreement between Bosnia and Herzegovina, on the one hand, and the Commission of European Communities on the other. In particular, in figures, the financial injection from IPA funds, intended for Bosnia and Herzegovina in the period from 2007 to 2013, according to the official data of the EU Delegation in Bosnia and Herzegovina, amounts to 624.802.360 Euros for assistance in transition and institution building, and 33.698.878 Euros for the development of cross-border cooperation. Funds intended for countries with a candidate status for EU membership are drastically higher than those on which Bosnia and Herzegovina is now entitled.

However, due to lack of fulfillment of conditions, Bosnia and Herzegovina, in total, only used half of the funds available to it. From the IPA allocation 2011, 2012, 2013, from projects that were not contracted or whose implementation could not be continued, as well as from savings generated after the procurement procedure, the European Commission realigned 42,24 million Euros for the Recovery Program from the consequences of the floods that hit Bosnia and Herzegovina in May 2014, so far, 10,3 million Euros has been allocated from IPA funds for technical assistance projects to local, regional and development of small and mediumsized enterprises, capacity building in the tourism industry, alignment with EU standards of central banking and insurance, and business support services provided to companies through the so-called, TAM / BAS program.

According to the findings of the 2014 Progress Report, Bosnia and Herzegovina has achieved a high level of trade integration with the European Union and the EU remains the main trading partner of Bosnia and Herzegovina, and further strengthened by Croatia's accession to the EU from July 1st 2013. Consequently, the share of exports to the European Union increased to $73,5 \%$, while imports from the European Union slightly decreased to $60 \%$ of total imports. The most important trade partners from the European Union are Germany and Croatia. CEFTA countries remain the second most important trading partner and account for $16 \%$ of exports of goods and $11 \%$ of imports.

The establishment and successful operation of regional development policy is not only a requirement that is placed before Bosnia and Herzegovina in the process of European integration, but also one of the basic mechanisms for more effective implementation of development policies in all relevant areas that have a direct impact on the quality of life of citizens. The current situation in Bosnia and Herzegovina is characterized by slow economic growth, insufficient support of the governments of Bosnia and Herzegovina in overall development, unemployment, slow development of the private sector and small and medium-sized enterprises, and insufficient use of available credit and donor funds, including funds from the EU. 
V.TULUMOVIĆ: Level and pace of the regional development of Bosnia and Herzegovina in the context of integration... EKONOMSKI PREGLED, 71 (2) 152-172 (2020)

Table 5.

\section{EUROPEAN UNION PROGRAM REVIEW 2014-2020 - POSSIBILITIES FOR BOSNIA AND HERZEGOVINA}

\begin{tabular}{|l|l|c|}
\hline \multicolumn{1}{|c|}{ Field } & \multicolumn{1}{|c|}{ Program title } & $\begin{array}{c}\text { Total } \\
\text { budget }(€)\end{array}$ \\
\hline Science and Innovation & $\begin{array}{l}\text { Framework Program for Research and } \\
\text { Innovation - Horizon 2020 }\end{array}$ & 77 billion \\
\hline $\begin{array}{l}\text { Competitiveness and } \\
\text { entrepreneurship }\end{array}$ & $\begin{array}{l}\text { Program for competitiveness of enterprises and } \\
\text { small and medium enterprises - COSME }\end{array}$ & 2,2 billion \\
\hline $\begin{array}{l}\text { Education, training, } \\
\text { youth and sports }\end{array}$ & Erasmus+ & 14 billion \\
\hline $\begin{array}{l}\text { Culture and audiovisual } \\
\text { activity }\end{array}$ & Creative Europe & 1,4 billion \\
\hline Civil society & Europe for Citizens & 185 million \\
\hline Social politics & Employment and Social Innovation Program & 919 million \\
\hline $\begin{array}{l}\text { Rights and non- } \\
\text { discrimination }\end{array}$ & Program for Rights, Equality and Citizenship & 439 million \\
\hline Health care & Health for development & 449 million \\
\hline Consumer protection & Consumer program & 449 million \\
\hline Environment protection & $\begin{array}{l}\text { Environmental and Climate Action Program - } \\
\text { LIFE }\end{array}$ & 3,4 billion \\
\hline Customs policy & Customs 2020 & 522 million \\
\hline Tax policy & Fiscalis 2020 & 223 million \\
\hline Finance & Pericles 2020 & 7 million \\
\cline { 2 - 3 } & Hercule III & 104 million \\
\hline Judiciary & Judiciary & 378 million \\
\hline Migration & Asylum and Migration Fund & 3 billion \\
\hline Security & $\begin{array}{l}\text { Internal Security Fund - border and visa } \\
\text { component }\end{array}$ & 2,7 billion \\
\cline { 2 - 3 } & Internal Security Fund - police component & 1 billion \\
\hline Civil protection & Union Civil Protection Instrument & 368 million \\
\hline $\begin{array}{l}\text { Trans-European } \\
\text { networks }\end{array}$ & The Europe Connecting Instrument & 33 billion \\
\hline Satellite systems & Galileo & 7,1 billion \\
\cline { 2 - 3 } & Copernicus & o \\
\hline
\end{tabular}

Source: EU Programs 2014-2020 Directorate for European Integration of the Council of Ministers of Bosnia and Herzegovina, 2014, p. 8-9. 
European integration and the acquisition of candidate country status should further motivate policy development towards regional development. In this context, the obligation to accept the principles of European regional policy, that is decentralization and subsidiarity, in partnership with the creation and implementation of regional development policies, should be the basis of a strategic commitment in this area. Priorities of the regional policy of Bosnia and Herzegovina should respect the priorities of the European Union. A regional approach in a range of segments, such as: the financial, legal or institutional segment can be more quickly contributed to a whole range of adjustments, in particular activities focused on the regional development and regional policy of Bosnia and Herzegovina.

The introduction and application of EU standards in Bosnia and Herzegovina in the field of regional development and cooperation will enable access to special programs for support to regional development.

\section{Conclusion}

Bosnia and Herzegovina is burdened with numerous political, social and economic problems. The basic path and way of overcoming these problems is economic development and economic stability. Acceptance and application of the Euro-region concept in Bosnia and Herzegovina, in addition to opening up the possibility of accessing EU funds for regional development, would contribute to the internal political and economic integration of Bosnia and Herzegovina, as well as the fulfillment of conditions for admission of the country into EU membership.

Bosnia and Herzegovina, like other countries in the region, can count on financial assistance from pre-accession funds, but great opportunities for economic and social development of the country are opened only by entering into full membership of the European Union. However, Bosnia and Herzegovina will have to have a clear strategy and a policy of regional development that will be acceptable to the European Union.

Bosnia and Herzegovina must persist in these challenges, implement the defined measures to eliminate the consequences of the economic crisis and ensure the unity of all actors that influence the creation of an economic environment, from the Government, executive and legislative authorities, to employers, scientific-educational institutions, trade unions and non-governmental organization. On the other hand, such consensus and implementation of the priorities and measures defined in the National Program for European Integration are necessary for the adoption of European standards and faster integration into the European family. 
Of course, in both of these processes we should not forget about strengthening the partnership with the countries in the region.

In order to achieve this goal, it is necessary to develop stable institutions that guarantee democracy, the rule of law, and the respect and protection of human and minority rights, to develop a market economy that can confront the pressure of competition within the European Union and it is necessary to implement harmonization of national legislation with legal acquisitions of the Union and, hence, take on obligations arising from membership. Undoubtedly, Bosnia and Herzegovina has a long and very difficult path to overcome in order to make it to the European integration. In a country with high unemployment and major social problems, eliminating the gray labor market is one of the priorities.

Low competitiveness of the economy is also one of the biggest problems. Much production has been shut down, interrupted by production chains, and new businesses slowly formed. Typically, the available resources are insufficient for successful functioning, especially for local development and capital investment in infrastructure and economy at the local level.

The empirical results of the research confirmed that Bosnia and Herzegovina faces a problem of regional development with a pronounced imbalance between the areas within the whole territory of Bosnia and Herzegovina. This confirms the need for systemic policy as well as regional development policy at the level of Bosnia and Herzegovina that would be in line with the policies of the European Union.

EU assistance policies towards Bosnia and Herzegovina are multiple, and one of these is the creation of five regions that combine historical, geographical, cultural, economic and other links of municipalities important for development. This is certainly a temporary solution to regionalization in Bosnia and Herzegovina, since the accession to the Structural Funds of the region will have to be regulated according to the Eurostat nomenclature, which implies NUTS 2 nomenclature for Bosnia and Herzegovina.

According to the preceding one, we can conclude that the correct regionalization and decentralization established on the one hand, according to the conditions and possibilities of Bosnia and Herzegovina, and on the other hand with the standards and policies, and especially the instruments of European Union assistance, would enable economically balanced development of all territorial units in Bosnia and Herzegovina, overall development and greater competitiveness of Bosnia and Herzegovina.

Regional development policy and processes of Bosnia and Herzegovina should be part of a strategic development plan that must be created on the basis of the joint action of state authorities and municipal / local units. This would create an environment for a successful regional policy, a greater absorption of funds from 
EU funds, as well as strengthening the competitiveness, institutional and legal capacity of local units and the country as a whole.

\section{References}

1. An analysis of the development of the EU Conditional Principles. (2010). $\mathrm{BiH}$, Council of Ministers, Directorate for European Integration, Sarajevo, p. 10-32. Available at: http://www.vijeceministara.gov.ba

2. Agency for Statistics of BiH, Sarajevo. Available at: http://www.bhas.ba.

3. Barbić, J. (2010). New Croatian Local and Regional Self-Government, HAZU, Zagreb.

4. Begić, K. (1997). Bosnia and Herzegovina from Vence's mission to the Dayton Agreement. Sarajevo, p. 116-117.

5. Bogunović, A. (1991). Regional economics, Zagreb.

6. Bošnjović, I. (1992). Regionalization of Bosnia and Herzegovina. Sarajevo, p. 91-98.

7. Central Bank of BiH. (2017). Report of the Central Bank of BiH for 2017, Sarajevo. Available at: www.cbbh.ba

8. Cooke, P. (2004). Evolution of regional innovation systems-emergence, theory, challenge for action. In: Cooke, P., et al. (Eds.) Regional Innovation Systems. Second ed. Routledge, London, p. 1-18.

9. Council of Ministers of BiH. (2011). Directorate for Economic Planning, BiH Development Report p. 12-13. Available at: http://www.vijeceministara.gov.ba

10. External Evaluation of the Instrument for Pre-accession Assistance (IPA II). (2017). Final Report,Volume 2, Evaluation carried out on behalf of the European Commission Annexes, p. 40-80. Available at: http://ec.europa.eu/commission/index_en

11. Hadžiomerović, H. (1984) Regional component as the factor of optimal development of the country, Proceedings, Faculty of Economics, University of Sarajevo, Sarajevo, p. 3.

12. Hodžić, K., (2011) Unemployment and improvement of the performance of the labor market in BiH, Proceedings no. 3, University / University "Vitez" Travnik, Travnik. Available at: https://unvi.edu.ba/Files/zbornici/FPE3.pdf

13. Hodžić, K. (2010). State of Economy and Economic Policy Measure in 2010, Faculty of Business Economics, University / University "Vitez" in Travnik, Vitez, p. 1-15. Available at: https://unvi.edu.ba/Files/zbornici/FPE3.pdf 
14. Hodžić, K. (2009). Bosnia and Herzegovina institutional constraints on addressing unemployment and possible unblocking in the period of crisis and exit. Proceedings from the 1st International Conference "How to manage in times of crisis" University of Tuzla Faculty of Economics, Tuzla. Available at: icei.epk.ba/wp-content/uploads/.../CONFERENCE_PROCEEDINGS_ ICEI_2013.pdf

15. Hodžić, K. (2008). Delayed Reform and the Challenges of Liberalization of Bosnia and Herzegovina Agriculture, Faculty of Economics Tuzla, Original Scientific Paper, Transition, Vol. 9, No.19-20, p. 63-78. Available at: testsite. infomanagement.co.rs/images/stories/.../Tranzicija-januar-decembar-2008. pdf

16. IPA funds in BiH. (2016). (Non) Used Opportunities and Opportunities, CCIs, p. 23-52. BiH Development Report. (2017). Available at: http://www. cci.ba/pubs/1/21/1.html

17. Kantalić, M. (2005). Regional Policy in the Process of Restructuring and Development, Master thesis, Zagreb, p. 3.

18. Klapić, M. (2013). Foreign direct investment in developing countries with a special focus on SEE countries Economic Newsletter, vol. XXVI, no. 1, University of Tuzla Faculty of Economics, Tuzla, p. 299-308. Available at: http:// www.efos.unios.hr/ekonomski-vjesnik/

19. Kubović, B. (1974). Regional Economics, Informator, Zagreb, p. 50-54.

20. Osmanković, J. (2001). Regionalization-Theory and Practice, Beta, Sarajevo.

21. Osmanković, J. (2002). The theory and policy of regional development of Bosnia and Herzegovina. Ed. Faculty of Economics, Sarajevo, p. 239.

22. Osmanković, J. (2004). Regionalization and regional development of Bosnia and Herzegovina in the postwar period. Review scientific article. Review scientific article. Proceedings Faculty of Economics in Zagreb,Year 2, Number 1, p. 35-44. Available at: https://hrcak.srce.hr/index.php?show=toc\&id_ broj=2344

23. Osmanković, J. (2014). Theory, politics and reality of regionalization and cooperation Faculty of Economics, University of Sarajevo, p. 672-681.

24. Papić, K. (1977). Economic Regionalization of Bosnia and Herzegovina, Review No. 11-12, Sarajevo, p. 24.28.

25. Pejanović, M. (2008). Historical design of regions and the possibility of establishing the regional structure of Bosnia and Herzegovina in the post-Dayton period. Proceedings from the International Conference: "Euroregions and Southeast Europe" of the University of Sarajevo Economic Institute Sarajevo, p. 45-68. Available at: library.fes.de/pdf-files/bueros/sarajevo/06044.pdf 
26. Rubić, K. (1999). The Impact of the War on Regional Development and Environmental Protection, Master thesis, Zagreb, p. 7-8.

27. Spahić, M. Jahić, H. (2014). Geographical regionalization of Bosnia and Herzegovina in the light of Euro-Atlantic integration, original scientific paper, University of Sarajevo, Faculty of Science, Sarajevo, p. 35-52.

28. Stojanović, R. (1981) Regional aspect of development, Proceedings, Belgrade, p. 40.

29. Study on the Impact of Regulations in the European Integration Process in Bosnia and Herzegovina, (2007). Application of Regulation (EC) No 1059/2003 of the European Parliament and of the Council of 26 May 2003 on the establishment of a common classification of territorial units for statistics (NUTS), Sarajevo, p. 1-7. Available at: http://www.dei.gov.ba

30. Šverko, M. (1995). Regional Development Management, Faculty of Economics Rijeka.

\title{
NIVO I TEMPO REGIONALNOG RAZVOJA BOSNE I HERCEGOVINE U KONTEKSTU INTEGRIRANJA U EUROPSKU UNIJU
}

\begin{abstract}
Sažetak
Glavni cilj ovog rada je ocjena nivoa i tempa regionalnog razvoja Bosne i Hercegovine sa jedne strane, te euroatlanski put $\mathrm{BiH}$ kao potencijalni kandidat za članstvo u Uniju sa druge strane. U empirijskom dijelu istraživanja prostorna komponenta obuhvatila je regionalizaciju Bosne i Hercegovine. Istraživanje je obuhvatilo i analizu procesa integriranja Bosne i Hercegovine u Evropsku uniju sa aspekta pretpristupne pomoći zemljama kandidatima i potencijalnim kandidatima u funkciji unapređenja regionalnog razvoja. Primarno istraživanje regionalnog razvoja i ocjene nivoa razvijenosti kao i obuhvat strukturnih politika u pogledu nadilaženja ključnih političkih, društvenih i ekonomskih problema, koji koče razvoj i unapređenje ekonomske integracije BiH prema Evropskoj uniji ograničeni su na teritoriju $\mathrm{BiH}$. Osnovne naučne metode, korištene u radu i davanja odgovora na istraživačka pitanja su historijska i komparativna metoda. Sastoje se od metoda i pokazatelja statističke analize (indeksi, stope rasta, pokazatelji učešća, koeficijenti, prosjeci). Posebne naučne metode korištene u postupku radu su: metoda analize, metoda sinteze, metoda indukcije, metoda deskripcije, metoda dedukcije, metoda klasifikacije, metoda komparacije. Empirijskim rezultatima istraživanja potvrđuje se da je Bosna i Hercegovina suočena sa problemom regionalnog razvoja sa izraženim debalansom među područjima unutar cijele teritorije BiH. To potvrđuje potrebu sistemske politike kao i politike regionalnog razvoja na nivou Bosne i Hercegovine koja bi bila usklađena sa politikama Evropske unije.
\end{abstract}

Ključne riječi: regionalni razvoj, politike regionalnog razvoja, integriranje u EU. 